\section{Dr. Gilbert Slater}

WE regret to record the death of Dr. Gilbert Slater, the economist and an authority on the culture and village life of southern India as it existed twenty years ago, which took place at Oxford on March 8 at the age of seventy-three years.

Slater was born in Plymouth on August 27, 1864, the son of Daniel Slater, a schoolmaster. A member of St. John's College, Cambridge, he was also a D.Sc. in Economics of the University of London, a degree to which, however, he was admitted so late as 1905. After leaving Cambridge he was for a time a schoolmaster; but he left the profession to take up lecturing, social work and political activities. In 1905 he was elected the first Labour mayor of Woolwich. The publication of his doctor's thesis in enlarged book form under the title "The English Peasantry and the enclosure of Common Fields" (1907) led to his appointment as head of Ruskin College, Oxford, in 1909. Here he remained until 1915, when he accepted the newly founded chair of Indian economies at the University of Madras. In 1921 he became publicity officer for Madras and a member of the Legislative Council. Slater returned to England in the following year, and in addition to lecturing at the London School of Economics and to Indian Civil Service students at Oxford, wrote a number of books on social and economic subjects, among which may be mentioned "The Growth of Modern England" (1932) and a final work on India, "Southern India, its Political and Economic Problems" (1936), as well as a chapter on the social and industrial history of Kent in the Victoria County History.

Of Slater's more active years, viewed in relation to scientific thought, the period which he spent in India was the most productive and influential. "Some South Indian Villages" (1917), which he edited, was based on surveys made by his students, whom he sent out with a questionnaire of his own devising to make first-hand observations of conditions in the villages with which each was well acquainted by residence. These intensive studies produced a mass of ethnographic and economic data, variable in quality, it is true, but of very considerable value. In the final form given by the editor, this report has had a profound effect on subsequent Indian political and sociological theory and practice. His analytical faculty also turned to the study of Indian culture and in his "The Dravidian Element in Indian Culture", published in 1923 after his return to England, he gave an orientation to the study of the place of the Dravidians in the development of Indian civilization, which, like his work on the Indian village in its special field, has greatly influenced the development of later Indian studies, although in directing attention to and emphasizing the affinities of the Dravidian and Mediterranean peoples, he was developing ideas already adumbrated by $\mathrm{Mr}$. F. J. Richards, as Dr. A. C. Haddon has pointed out (see "The Races of Man", by A. C. Haddon, 1924 , p. 150, where Slater is, curiously, miscalled "Scott").

\section{Mr. F. J. Hanbury}

Mr. F. J. Hanbury, who died on March 1 at the age of eighty-six years, was the son of Cornelius Hanbury, of the firm of Messrs. Allen and Hanbury, wholesale druggists. He was educated at the Friends' School, Tottenham, and afterwards studied pharmacy, passing with honours the two examinations of the Pharmaceutical Society. $\mathrm{He}$ joined his father's business in 1872, becoming a partner and eventually chairman of the firm in 1916.

In the 'eighties Mr. Hanbury formed a friendship with the late Rev. E. S. Marshall and became interested in British flowering plants. The two explored the northern Scottish Highlands together, and Hanbury began a study of the difficult genus Hieracium. Of this group he described several new species, and in 1889 published the first instalment of a sumptuously illustrated monograph. Before this work had proceeded far, however, it was found impracticable to continue it in the manner contem. plated, and it was abandoned. Mr. Hanbury then turned his energies to the production of a flora of Kent, with Marshall as collaborator, and this was completed and published in 1899.

From this date Hanbury did little further botanical work, but he continued to act as editor of the "London Catalogue of British Plants". For some time he took a keen interest in entomology, but after his removal to East Grinstead he devoted himself to the development of his magnificent garden and the cultivation of tropical orchids. He was a prominent member of the Royal Horticultural Society, serving on the scientific and other committees, and was a recipient of the Society's Victoria Medal of Honour. He was almost the 'father' of the Linnean Society, which he had joined in 1873 . He recently presented to the Botanical Department of the British Museum (Natural History) the important herbarium of Dr. Boswell Syme, which he had acquired many years previously.

H. W. Pugsley.

WE regret to announce the following deaths:

Prof. J. E. Coover, emeritus professor of psychology in Stanford University, on February 19, aged sixtyfive years.

Sir Raymond Crawfurd, registrar of the Royal College of Physicians of London, known for his work on the history of medicine, on March 9, aged seventytwo years.

Sir Reginald Fleming Johnston, K.C.M.G., C.B.E., formerly commissioner for Wei-hai-wei, an authority on the Chinese language and people, on March 6, aged sixty-four years.

Major A. D. Lumb, of the Scientific and Technical Department of the Imperial Institute, known for his work on the geology and mineral survey of southern Nigeria and the Udi Okana coalfield.

Prof. A. Magnan, professor of animal mechanics applied to aviation in the Collège de France, aged fifty-seven years.

Mr. Melville Hilton-Simpson, the distinguished traveller and ethnologist, on March 17, aged fifty. seven years. 